\title{
CHARACTERIZATION OF SURFACE WATER QUALITY ALONG A WATERSHED DISTURBANCE GRADIENT'1
}

\author{
Robert A. Zampella ${ }^{2}$
}

\begin{abstract}
Characterizing ecological indicators such as water quality is necessary to effectively manage human-dominated systems such as the New Jersey Pinelands. Pinelands surface waters are naturally acidic and low in nutrients and other dissolved substances. Water quality for 14 Pinelands stream sites monitored by the U.S. Geological Survey was characterized in relation to land use. A gradient of increasing $\mathrm{pH}$, specific conductance, and concentration of dissolved calcium, dissolved magnesium, total nitrite + nitrate-nitrogen, total ammonia-nitrogen, and total phosphorus was associated with a watershed disturbance gradient of increasing land use intensity and waste water flow. These two parallel gradients emphasized the significant effect that watershed disturbance can have on natural water chemistry in the Pinelands. The results of this study can be applied to planning and regulatory programs in the Pinelands.

(KEFY TERMS: land use; New Jersey Pinelands; watershed disturbance gradient; water quality.)
\end{abstract}

\section{INTRODUCTION}

Several current initiatives focus on the need to develop sustainable ecosystems (Lubchenco et al., 1991; Kessler et al., 1992). Sustainability is an especially important issue in human-dominated systems such as the New Jersey Pinelands. Selecting appropriate ecological indicators, such as water quality, and characterizing the effects of human activities on these ecological attributes is a prerequisite for the effective management of such systems (Harwell, 1990; Lubchenco et al., 1991).

Management of the 445,000 ha New Jersey Pinelands area, which has been designated as a National Reserve by the U.S. Congress and a Biosphere Reserve in the Man and the Biosphere Program
(MAB), is directed by a comprehensive regional planning and regulatory program that affects a broad range of land use activities (Pinelands Commission, 1980; Collins and Russell, 1988). Undisturbed surface waters in the New Jersey Pinelands are usually characterized as acidic, low in nutrients and other dissolved substances, and highly susceptible to watershed disturbance (Patrick et al., 1979; Yuretich et al., 1981; Morgan and Good, 1988). The ecological consequences of human-related watershed disturbance in the Pinelands include changes in the composition of communities of periphyton (Morgan, 1987), macrophytes (Morgan and Philipp, 1986), zooplankton (Morgan, 1985; 1986), macroinvertebrates (Dougherty and Morgan, 1991), fish (Hastings, 1984), and forested wetlands (Ehrenfeld, 1983; Ehrenfeld and Schneider, 1991).

Although several studies have described the water chemistry of both disturbed and undisturbed Pinelands streams (Yuretich et al., 1981; Fusillo, 1981; Durand and Zimmer, 1982; Morgan and Good, 1988), the full range of surface water quality conditions found in the Pinelands has not been adequately examined. The purpose of this paper is to describe and compare the water quality of Pinelands streams draining watersheds representing a broad range of geographic locations and land use characteristics. The results may be applied to the development of planning and regulatory programs that reflect the variable conditions and permitted land uses found throughout the Pinelands. 


\section{METHODS}

The New Jersey Pinelands lie on the Atlantic Coastal Plain in southern New Jersey. The principal aquifer is the Kirkwood-Cohansey (Rhodehamel, 1979a), a water table reservoir that exerts considerable influence on the structure and function of the Pinelands ecosystem (Ballard, 1979; Whittaker, 1979). Quartzose sands dominate the Kirkwood and Cohansey formations (Rhodehamel, 1979b), and ground water discharge from the aquifer accounts for 89 percent of annual stream discharge (Rhodehamel, 1979a).

Using the same 11-year (October 1975-September 1986) U.S. Geological Survey data set analyzed by Hay and Campbell (1990), summary statistics were calculated for each of the 14 water quality monitoring stations located on Pinelands streams (Table 1, Figure 1). The summary statistics included first, second (median), and third quartile values for specific conductance, $\mathrm{pH}$, dissolved calcium, dissolved magnesium, total nitrite + nitrate-nitrogen, total ammonianitrogen, and total phosphorus. Using the median values, Spearman rank correlation coefficients were calculated to evaluate the intensity of association among the seven variables. Separate medians were also calculated for (1) high flow periods (NovemberApril) and (2) low flow periods (May-October) for the 11 years to assess seasonal variations in water chemistry due to differences in discharge, temperature, and biological activity (Morgan and Good, 1988; Hay and Campbell, 1990).

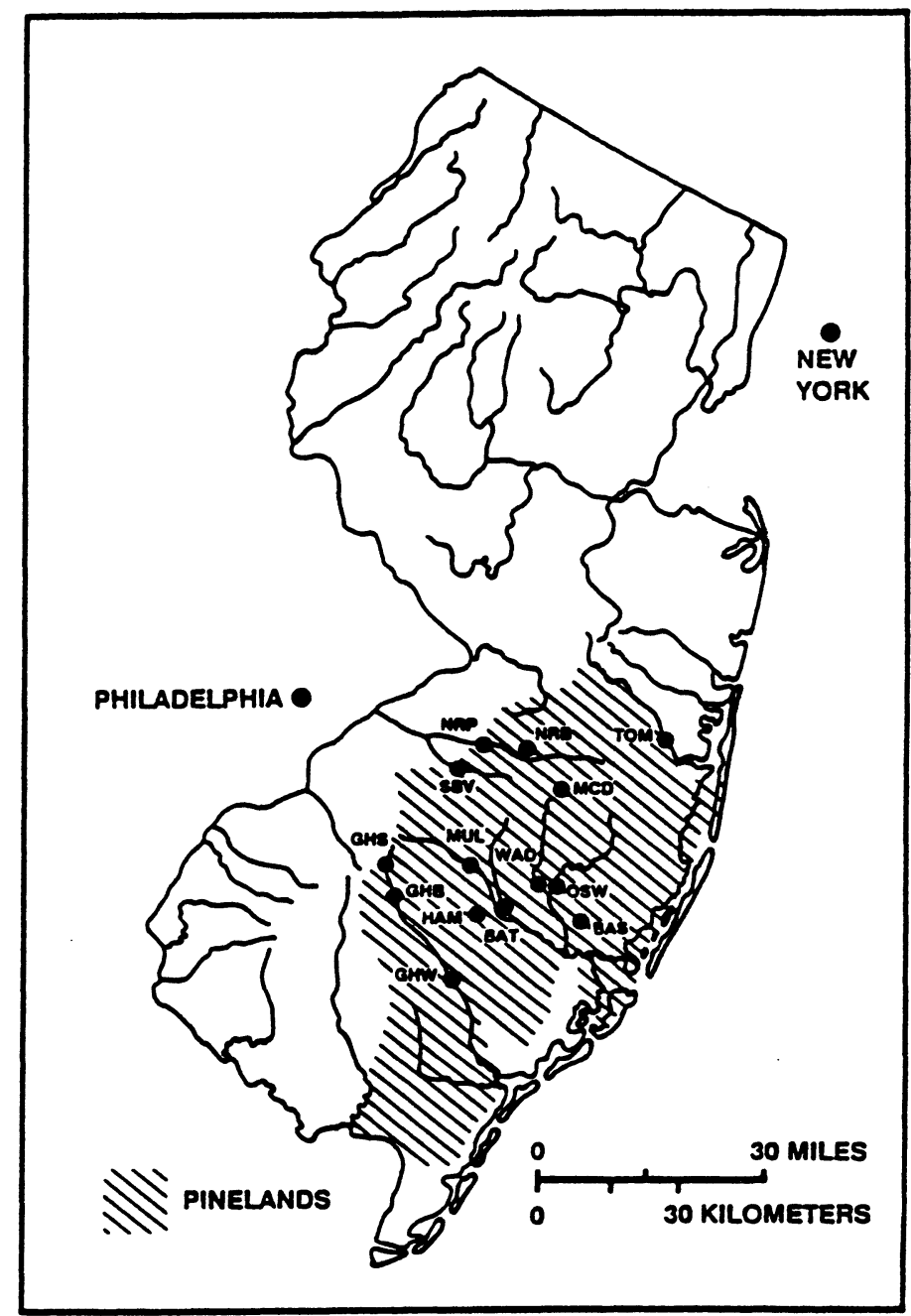

Figure 1. Location of U.S. Geological Survey Water Quality Monitoring Stations in the New Jersey Pinelands.

Refer to Table 1 for explanation of stream station symbols.

TABLE 1. Pinelands Surface Water Quality Stations Monitored by the U.S. Geological Survey.

\begin{tabular}{|c|c|c|c|c|}
\hline $\begin{array}{c}\text { Station } \\
\text { Number }\end{array}$ & $\begin{array}{l}\text { Station } \\
\text { Symbol }\end{array}$ & Station Name & $\begin{array}{c}\text { Drainage } \\
\text { Area } \\
\text { (mi2) }\end{array}$ & $\begin{array}{c}\text { Drainage } \\
\text { Area } \\
\left(\mathbf{c m}^{2}\right)\end{array}$ \\
\hline 01408500 & TOM & Toms River Near Toms River & 123.0 & 318.6 \\
\hline 01409387 & MUL & Mullica River at Outlet of Atsion Lake & 26.7 & 69.2 \\
\hline 01409416 & HAM & Hammonton Creek at Wescoatville & 9.6 & 24.8 \\
\hline 01409500 & BAT & Batsto River at Batsto & 67.8 & 175.6 \\
\hline 01409815 & WAD & West Branch Wading River at Maxwell & 85.9 & 222.5 \\
\hline 01410000 & OSW & Oswego River at Harrisville & 72.5 & 187.8 \\
\hline 01410150 & BAS & East Branch Bass River Near New Gretna & 8.1 & 21.0 \\
\hline 01410784 & GHS & Great Egg Harbor River Near Sicklerville & 15.1 & 39.1 \\
\hline 01410820 & GHB & Great Egg Harbor River Near Blue Anchor & 37.3 & 96.6 \\
\hline 01411110 & GHW & Great Egg Harbor River at Weymouth & 154.0 & 398.9 \\
\hline 01465850 & SBR & South Branch Rancocas Creek at Vincentown & 64.5 & 167.1 \\
\hline 01465970 & NRP & North Branch Rancocas Creek at Browns Mills & 27.4 & 71.0 \\
\hline 01466500 & MCD & McDonalds Branch in Lebanon State Forest & 2.4 & 6.1 \\
\hline 01467000 & NRB & North Branch Rancocas Creek at Pemberton & 118.0 & 305.6 \\
\hline
\end{tabular}


All available data were included in the analysis. Sample size varied among factors and stations due to differences in sampling frequency. Phosphorus, nitrite + nitrate-nitrogen, and ammonia-nitrogen data were edited prior to analysis. Nitrite + nitratenitrogen data, rather than nitrate data were used because the former variable was measured more frequently and nitrite represented only a small fraction of the combined measurement. Many censored observations (values reported as below detection limits) were reported for each of these three water quality variables, and detection limits varied considerably. For phosphorus, all censored values with detection limits greater than $0.02 \mathrm{mg} / \mathrm{l}$ were deleted. For the two nitrogen species, all censored values with detection limits greater than $0.10 \mathrm{mg} /$ were deleted. All censored values were equated to zero when calculating the summary statistics, but the respective detection limits were used when reporting the results.

Land use profiles (Table 2) for each of the drainage basins were also prepared using U.S. Geological Survey land cover data (Mitchell et al., 1977) and waste water discharge data reported by the Pinelands Commission (1980). Land use cover classes include urban, agricultural, and forest land. Percentages shown in Table 2 do not total 100 percent because all land use types are not shown. Although the land cover information is from the late 1960 s to early 1970 s, it still reflects relative differences among these areas. With the exception of portions of Ocean County located within the Toms River basin, most development that occurred in the Pinelands during the 1970's was located along the region's perimeter (Pinelands Commission, 1980).
The land use profiles were used to develop a generalized watershed disturbance gradient. Drainage areas were ordered by: (1) separating those with waste water discharges from those without discharges and (2) ranking basins within these two groups according to their combined urban and agricultural land coverage (Table 2).

\section{RESULTS AND DISCUSSION}

A water quality gradient of increasing $\mathrm{pH}$, specific conductance, and calcium, magnesium, nitratenitrogen, ammonia nitrogen, and total phosphorus concentrations paralleled the watershed disturbance gradient characterized by increasing land use intensity (percent developed and agricultural land) and waste water flow (Figure 2). A high positive correlation existed among all seven water quality variables (Table 3).

McDonalds Branch, shown at the extreme left end of the disturbance gradient, is a U.S. Geological Survey Hydrologic Benchmark station. Benchmark stations comprise a national network of water quality stations located in small, undeveloped watersheds. Thus, McDonalds Branch provides an excellent standard for water quality in undisturbed Pinelands watersheds. Hammonton Creek displayed the greatest degree of watershed disturbance. The land use characteristics of this drainage basin contrast sharply with those drainage basins that are dominated by forest land.

TABLE 2. Land Use Characteristics of Pinelands Watersheds.

\begin{tabular}{|c|c|c|c|c|c|}
\hline \multirow[b]{2}{*}{ Station Name } & \multirow{2}{*}{$\begin{array}{c}\text { Sewage } \\
\text { Flow } \\
\left(1000 / \mathrm{gal} / \mathrm{day} / \mathrm{mi}^{2}\right)\end{array}$} & \multicolumn{4}{|c|}{ Percent Land Cover } \\
\hline & & Forested & Urban & Agricultural & $\begin{array}{c}\text { Total } \\
\text { Altered }\end{array}$ \\
\hline McDonalds Branch in Lebanon State Forest & 0 & 96.0 & 0.0 & 0.0 & 0.0 \\
\hline East Branch Bass River Near New Gretna & 0 & 86.9 & 3.2 & 0.0 & 3.2 \\
\hline Oswego River at Harrisville & 0 & 80.6 & 3.6 & 2.6 & 6.2 \\
\hline West Branch Wading River at Maxwell & 0 & 68.4 & 0.5 & 9.5 & 10.0 \\
\hline Batsto River at Batsto & 0 & 54.8 & 0.9 & 14.9 & 15.8 \\
\hline Mullica River at Outlet of Atsion Lake & 0 & 53.4 & 9.4 & 6.9 & 16.3 \\
\hline Toms River Near Toms River & 4.4 & 57.1 & 10.1 & 4.6 & 14.7 \\
\hline North Branch Rancocas Creek at Pemberton & 4.4 & 60.8 & 10.1 & 7.8 & 17.9 \\
\hline North Branch Rancocas Creek at Browns Mills & 3.6 & 54.1 & 25.6 & 3.7 & 29.3 \\
\hline South Branch Rancocas Creek at Vincentown & 4.6 & 39.8 & 7.0 & 26.6 & 33.6 \\
\hline Great Egg Harbor River at Weymouth & 5.4 & 45.3 & 16.2 & 19.7 & 35.9 \\
\hline Great Egg Harbor River Near Blue Anchor & 21.4 & 41.1 & 24.8 & 18.5 & 43.3 \\
\hline Great Egg Harbor River Near Sicklerville & 53.0 & 41.8 & 32.3 & 14.7 & 47.0 \\
\hline Hammonton Creek at Wescoatville & 76.0 & 17.4 & 22.5 & 50.1 & 72.6 \\
\hline
\end{tabular}



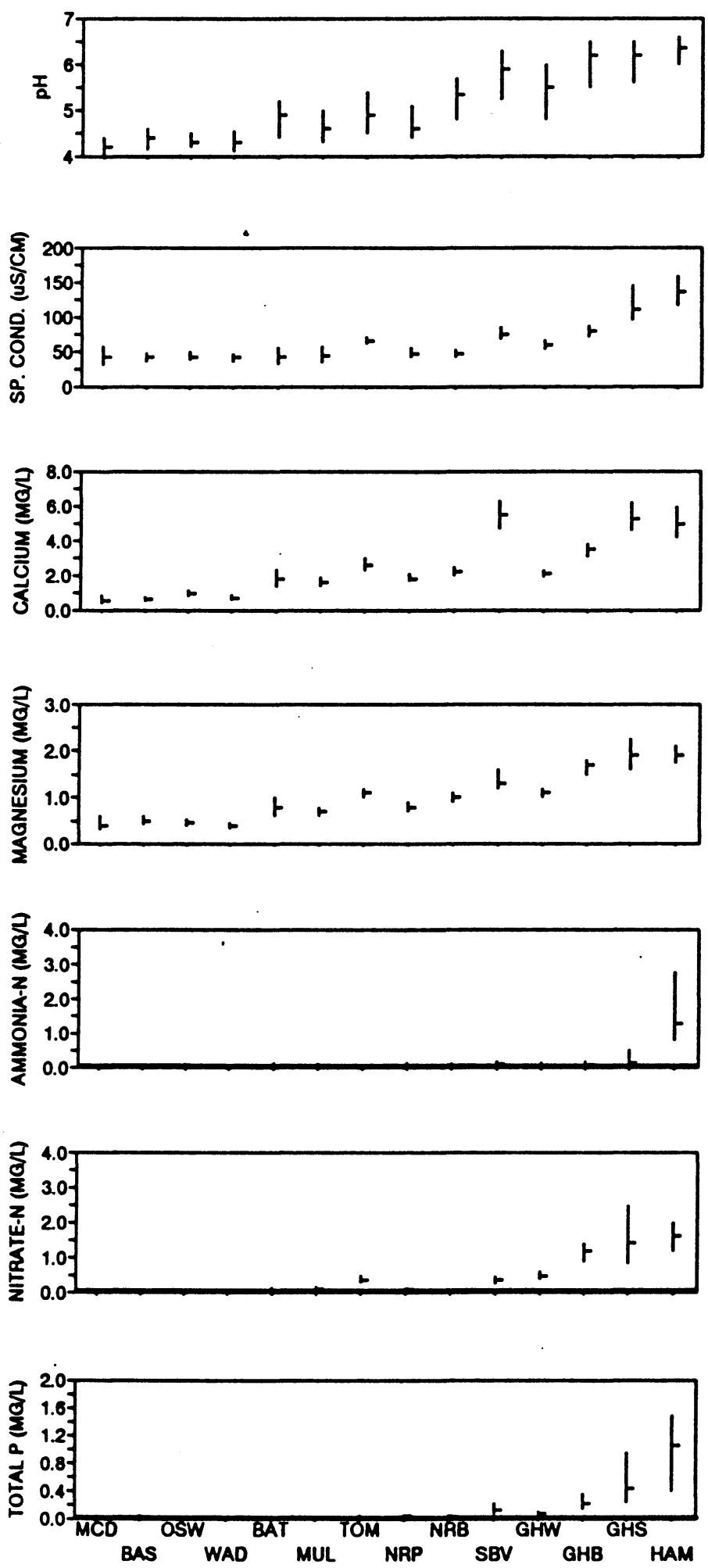

WATERSHED DISTURBANCE GRADIENT

Figure 2. Pinelands Surface Water Quality Gradients. Shaded areas show detection limits for total phosphorus $(0.02 \mathrm{mg} / 1)$, total ammonia- $\mathrm{N}(0.10 \mathrm{mg} /)$, and total nitrite + nitrate- $\mathrm{N}(0.10 \mathrm{mg} /)$.
Along with McDonalds Branch, Bass River, Oswego River, and Wading River are the least disturbed drainage areas. The high percentage of altered land in the Wading River is due to extensive cranberry and blueberry lands rather than upland farmland which dominates in other basins with high agricultural cover. Lime and fertilizer requirements of these berry crops are low compared to those of most upland crops (Pinelands Commission, 1980).

The Batsto River and Mullica River drainage areas represent basins with moderate urban or agricultural land cover and no sewage discharges. The Toms River, North Branch Rancocas, South Branch Rancocas, and Great Egg Harbor River at Weymouth drainage areas have comparable waste water discharge levels although agricultural land cover is higher in the latter two basins. The two other Great Egg Harbor River drainage areas and Hammonton Creek can be characterized as urban/agricultural basins with relatively high waste water flows. Water quality characteristics associated with these four general watershed types are shown in Table 4.

Very low pH and calcium and magnesium concentrations distinguished water quality in the four least disturbed (McDonalds Branch, Bass River, Oswego River, and Wading River) streams from all other stream stations. These streams also displayed especially small cation and $\mathrm{pH}$ interquartile ranges.

Specific conductance and dissolved calcium and magnesium concentrations were generally higher during high flow periods, while $\mathrm{pH}$ was highest during low flow periods (Figure 3). Similar trends have been observed in other Pinelands studies (Fusillo et al., 1980; Morgan and Good, 1988). However, seasonality appeared to have only a minor effect on the basic water quality gradient.

Nitrite + nitrate-nitrogen concentrations were $<0.10 \mathrm{mg} / \mathrm{l}$ in the four least disturbed streams. They were also low in several streams that occupied an intermediate position in the disturbance gradient. The high nitrite + nitrate-nitrogen detection limit probably partially obscured the distinction between these streams and the least disturbed streams. Although domestic sewage discharges have been identified as a major reason for the extremely high nitrite + nitrate-nitrogen concentrations observed in the two upper Great Egg Harbor River stations and Hammonton Creek (Fusillo, 1981; Schornick and Ram, 1978), the changes observed along the watershed disturbance gradient probably reflect both point and nonpoint sources, including agricultural activities.

Yuretich et al. (1981) found a similar contrast in calcium and magnesium levels between undisturbed Pinelands streams and Toms River, Mullica River, and Batsto River stream stations. They attributed the higher levels in the Toms River to human activities 
TABLE 3. Spearman Rank Correlation Coefficients $(P<0.001)$.

\begin{tabular}{llclllll}
\hline & pH & $\begin{array}{c}\text { Specific } \\
\text { Conductance }\end{array}$ & TP & NO $_{2}+\mathrm{NO}_{3}$ & NH3 & Ca & Mg \\
\hline pH & 1.00 & & & & & & \\
Specific Conductance & 0.91 & 1.00 & & & & & \\
Total P & 0.95 & 0.91 & 1.00 & & & \\
$\mathrm{NO}_{2}+\mathrm{NO}_{3}-\mathrm{N}$ & 0.84 & 0.93 & 0.85 & 1.00 & & \\
$\mathrm{NH}_{3}-\mathrm{N}$ & 0.79 & 0.81 & 0.80 & $0.77^{*}$ & 1.00 & & \\
$\mathrm{Ca}$ & 0.92 & 0.92 & 0.86 & 0.79 & $0.78^{*}$ & 1.00 & \\
$\mathrm{Mg}$ & 0.98 & 0.95 & 0.94 & 0.88 & 0.79 & 0.95 & 1.00 \\
\hline
\end{tabular}

${ }^{*} \mathrm{P}=0.001$.

TABLE 4. Water Quality Characteristics of Pinelands Streams.

\begin{tabular}{|c|c|c|c|c|}
\hline & \multicolumn{4}{|c|}{ LAND USE INTENSTTY } \\
\hline & Low & Moderate & Moderate-High & High \\
\hline & \multicolumn{4}{|c|}{ SEWAGE FLOW } \\
\hline & None & None & Low & Moderate-High \\
\hline \multirow[b]{2}{*}{ Factors } & \multicolumn{4}{|c|}{ STREAM GROUPS } \\
\hline & $\begin{array}{l}\text { MCD, BAS, } \\
\text { OSW, WAD }\end{array}$ & BAT, MUL & $\begin{array}{c}\text { TOM, NRP, NRB } \\
\text { SBV, GHW }\end{array}$ & $\begin{array}{c}\text { GHB, GHS, } \\
\text { HAM }\end{array}$ \\
\hline $\begin{array}{c}\text { pH (standard units) } \\
\text { 1st Quartile } \\
\text { Median } \\
\text { 3rd Quartile }\end{array}$ & $\begin{array}{l}4.0-4.2 \\
4.2-4.4 \\
4.4-4.6\end{array}$ & $\begin{array}{l}4.3-4.4 \\
4.6-4.9 \\
5.0-5.2\end{array}$ & $\begin{array}{l}4.4-5.3 \\
4.6-5.9 \\
5.1-6.3\end{array}$ & $\begin{array}{l}5.5-6.0 \\
6.2-6.4 \\
6.5-6.6\end{array}$ \\
\hline $\begin{array}{l}\text { Specific Conductance } \\
\text { 1st Quartile } \\
\text { Median } \\
\text { 3rd Quartile }\end{array}$ & $\begin{array}{r}31-39 \\
42 \\
47-58\end{array}$ & $\begin{array}{l}32-35 \\
42-44 \\
56-57\end{array}$ & $\begin{array}{l}42-68 \\
47-75 \\
53-86\end{array}$ & $\begin{array}{l}71-117 \\
79-136 \\
87-159\end{array}$ \\
\hline $\begin{array}{l}\text { Calcium, Dissolved (n } \\
\text { 1st Quartile } \\
\text { Median } \\
\text { 3rd Quartile }\end{array}$ & $\begin{array}{l}0.4-0.8 \\
0.5-1.0 \\
0.8-1.2\end{array}$ & $\begin{array}{r}1.4 \\
1.6-1.8 \\
1.9-2.4\end{array}$ & $\begin{array}{l}1.7-4.7 \\
1.8-5.5 \\
2.1-6.3\end{array}$ & $\begin{array}{l}3.1-4.6 \\
3.5-5.3 \\
3.8-6.2\end{array}$ \\
\hline $\begin{array}{c}\text { Magnesium, Dissolve } \\
\text { 1st Quartile } \\
\text { Median } \\
\text { 3rd Quartile }\end{array}$ & $\begin{array}{l}0.3-0.4 \\
0.4-0.5 \\
0.5-0.6\end{array}$ & $\begin{array}{r}0.6 \\
0.7-0.8 \\
0.8-1.0\end{array}$ & $\begin{array}{l}0.7-1.2 \\
0.8-1.3 \\
0.9-1.6\end{array}$ & $\begin{array}{l}1.5-1.8 \\
1.7-1.9 \\
1.8-2.3\end{array}$ \\
\hline $\begin{array}{l}\text { Ammonia-N, Total (m } \\
\text { 1st Quartile } \\
\text { Median } \\
\text { 3rd Quartile }\end{array}$ & $\begin{array}{r}<0.10 \\
<0.10 \\
<0.10-0.12\end{array}$ & $\begin{array}{r}<0.10 \\
<0.10 \\
0.13-0.15\end{array}$ & $\begin{array}{r}<0.10 \\
<0.10-0.12 \\
0.11-0.20\end{array}$ & $\begin{array}{r}<0.10-0.81 \\
0.10-1.29 \\
0.19-28\end{array}$ \\
\hline $\begin{array}{c}\text { Nitrite + Nitrate-N, T } \\
\text { 1st Quartile } \\
\text { Median } \\
\text { 3rd Quartile }\end{array}$ & $\begin{array}{l}<0.10 \\
<0.10 \\
<0.10\end{array}$ & $\begin{array}{r}<0.10 \\
<0.10-0.12 \\
0.15-0.17\end{array}$ & $\begin{array}{r}<0.10-0.39 \\
<0.10-0.47 \\
0.10-0.60\end{array}$ & $\begin{array}{l}0.83-1.20 \\
1.20-1.62 \\
1.40-2.49\end{array}$ \\
\hline $\begin{array}{l}\text { Phosphorus, Total (m } \\
\text { 1st Quartile } \\
\text { Median } \\
\text { 3rd Quartile }\end{array}$ & $\begin{array}{r}<0.02 \\
<0.02-0.03 \\
<0.02-0.06\end{array}$ & $\begin{array}{r}<0.02-0.02 \\
0.03 \\
0.04\end{array}$ & $\begin{array}{l}0.02-0.07 \\
0.03-0.13 \\
0.06-0.22\end{array}$ & $\begin{array}{l}0.14-0.40 \\
0.22-1.06 \\
0.36-1.50\end{array}$ \\
\hline
\end{tabular}



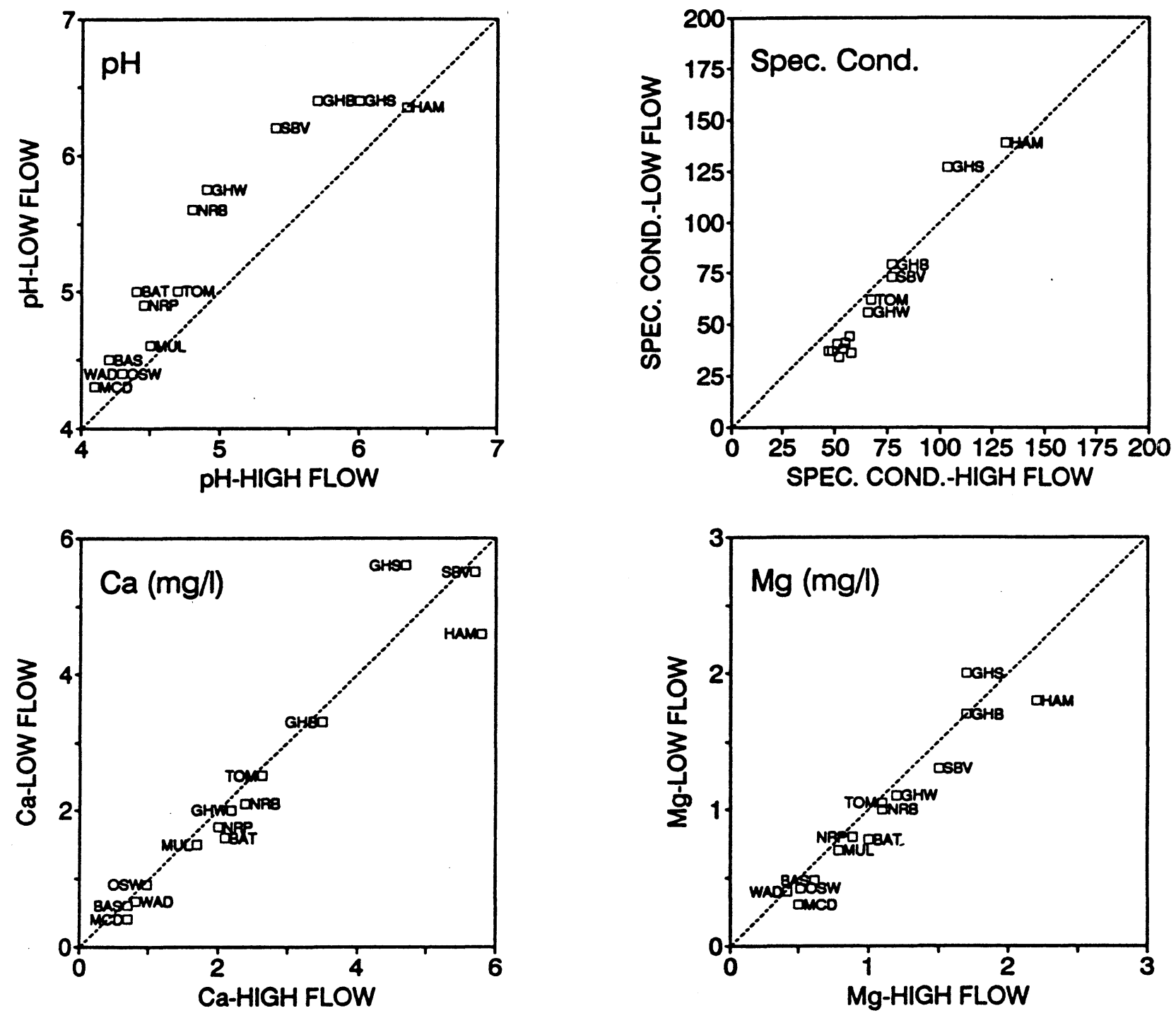

Figure 3. High Flow (November-April) and Low Flow (May-October) Median Water Quality Values.

but suggested that deep ground water contributions were the primary source of the higher cation concentrations in the other two streams. Morgan and Good (1988), who more accurately characterized the type and extent of land use disturbance in the headwaters of the Mullica River and Batsto River, associated elevated calcium and magnesium levels in these streams with watershed disturbance.

Ammonia-nitrogen concentrations were low and generally comparable in all but the four streams occupying the extreme end of the disturbance gradient. The relatively high phosphorus concentrations $(>0.02$ $\mathrm{mg} / \mathrm{l}$ ) reported here for McDonalds Branch, Bass River, Oswego River, and Wading River may be due in part to analytical limitations. However, differences in phosphorus levels observed along the disturbance gradient appear to reflect actual conditions rather than analytical error. As with nitrite + nitrate-nitrogen concentrations, sewage discharges are reported to have a substantial effect on phosphorus levels in the upper Great Egg Harbor River stations and Hammonton Creek and ammonia levels in Hammonton Creek (Fusillo, 1981; Schornick and Ram, 1978).

This study documents the wide range of water quality characteristics found in the Pinelands and highlights the significant effect that watershed disturbance can have on natural water chemistry. Substantial changes in all the major water quality variables analyzed were associated with a gradient of varying urban and agricultural land use intensity and domestic waste water flow. The results can be used in the development of water quality programs and policies that reflect both the differences in watershed characteristics found in the Pinelands and the range of land uses allowed in the region. 


\section{ACKNOWLEDGMENTS.}

I thank Keith Robinson and Kathleen Laubach for providing the raw U.S. Geological Survey water chemistry data and land cover data, Martha Windisch for assisting with the data analysis, and Lyda Craig and John Bunnell for assisting in the preparation of the graphics. I also thank Mark Morgan, Keith Robinson, and Peter Morin for reviewing an earlier manuscript. The comments of R. Peter Richards and several anonymous reviewers are also appreciated. This study was supported by the New Jersey Pinelands Commission.

\section{LTTERATURE CITED}

Ballard, J. T., 1979. Fluxes of Water and Energy Through the Pine Barrens Ecosystems. In: Pine Barrens: Ecosystem and Landscape, R. T. T. Forman (Editor). Academic Press, New York, New York. pp. 133-146.

Collins, B. R. and E. W. B. Russell, 1988. Protecting the New Jersey Pinelands. Rutgers University Press, New Brunswick, New Jersey.

Dougherty, J. E. and M. D. Morgan, 1991. Benthic Community Response (Primarily Chironomidae) to Nutrient Enrichment and Alkalinization in Shallow, Soft Water Humic Lakes. Hydrobiologia 215:73-82.

Durand, J. B. and B. J. Zimmer, 1982. Pinelands Surface Water Chemistry, Part I. Center for Coastal and Environmental Studies, Rutgers, the State University of New Jersey, New Brunswick, New Jersey, 262 pp.

Ehrenfeld, J. G., 1983. The Effects of Changes in Land-Use on Swamps of the New Jersey Pine Barrens. Biological Conservation 25:353-375.

Ehrenfeld, J. G. and J. P. Schneider, 1991. Chamaecyparis thyoides Wetlands and Suburbanization: Effects on Hydrology, Water Quality and Plant Community Composition. Journal of Applied Ecology 28:467-490.

Fusillo, T. V., 1981. Impact of Suburban Residential Development on Water Resources in the Area of Winslow Township, Camden County, New Jersey. U.S. Geological Survey Water Resources Investigation 81-27. U.S. Geological Survey, Trenton, New Jersey, $38 \mathrm{pp}$.

Fusillo, T. V., J. C. Schornick, Jr., H. E. Koester, and D. A. Harriman, 1980. Investigation of Acidity and Other Water-Quality Characteristics of Upper Oyster Creek, Ocean County, New Jersey. U.S. Geological Survey Water Resources Investigation 8010, U.S. Geological Survey, Trenton, New Jersey, 30 pp.

Harwell, M. A., C. C. Harwell, D. A. Weinstein, and J. R. Kelly, 1990. Characterizing Ecosystem Response to Stress. In: Ecological Risks, W. G. Grodzinski, E. B. Cowling, A. I. Breymeyer, A. S. Phillips, S. I. Auerbach, A. M. Bartuska, and M. A. Harwell (Editors). National Academy Press, Washington, D.C.

Hastings, R. W., 1984. The Fishes of the Mullica River, a Naturally Acid Water System of the New Jersey Pine Barrens. Bulletin of the New Jersey Academy of Sciences 29:9-23.

Hay, L. E. and J. P. Campbell, 1990. Water-Quality Trends in New Jersey Streams. U.S. Geological Survey Water-Resources Investigation Report 90-4046, West Trenton, New Jersey, 297 pp.

Kessler, W. B., H. Salwasser, C. W. Cartwright, Jr., and J. A. Caplan, 1992. New Perspectives for Sustainable Natural Resources Management. Ecological Applications 2:221-225.

Lubchenco, J., A. M. Olson, L. B. Brubaker, S. R. Carpenter, M. M. Holland, S. P. Hubbell, S. A. Levin, J. A. MacMahon, P. A. Matson, J. M. Melillo, H. A. Mooney, C. H. Peterson, H. R. Pulliam, L. A. Real, P. J. Regal, and P. G. Risser, 1991. The Sustainable Biosphere Initiative: An Ecological Research Agenda. Ecology 72:371-412.
Mitchell, W. B., S. C. Guptill, K. E. Anderson, R. C. Fegeas, and C. A. Hallam, 1977. GIRAS: A Geographic Information Retrieval and Analysis System for Handling Land Use and Land Cover Data. U.S. Geological Survey Professional Paper 1059, 16 pp.

Morgan, M. D., 1985. Photosynthetically Elevated pH in Acid Waters with High Nutrient Content and its Significance for the Zooplankton Community. Hydrobiologia 128:239-247.

Morgan, M. D., 1986. The Effect of Altered pH on Zooplankton Community Structure in a Disturbed New Jersey Pine Barrens Pond. Journal of Freshwater Ecology 3:467-476.

Morgan, M. D., 1987. Impact of Nutrient Enrichment and Alkalinization on Periphyton Communities in the New Jersey Pine Barrens. Hydrobiologia 144:233-241.

Morgan, M. D. and R. E. Good, 1988. Stream Chemistry in the New Jersey Pinelands: The Influence of Precipitation and Watershed Disturbance. Water Resources Research 24:1091-1100.

Morgan, M. D. and K. R. Philipp, 1986. The Effect of Agricultural and Residential Development on Aquatic Macrophytes in the New Jersey Pine Barrens. Biological Conservation 35:143-158.

Patrick, R., B. Matson, and L. Anderson, 1979. Streams and Lakes in the Pine Barrens. In: Pine Barrens: Ecosystem and Landscape, R. T. T. Forman (Editor). Academic Press, New York, New York, pp. 189-193.

Pinelands Commission, 1980. Comprehensive Management Plan for the Pinelands National Reserve and Pinelands Area. Pinelands Commission, New Lisbon, New Jersey.

Rhodehamel, E. C., 1979a. Hydrology of the New Jersey Pine Barrens. In: Pine Barrens: Ecosystem and Landscape, R. T. T. Forman (Editor). Academic Press, New York, New York, pp. 147-167.

Rhodehamel, E. C. 1979b. Geology of the Pine Barrens of New Jersey. In: Pine Barrens: Ecosystem and Landscape, R. T. T. Forman (Editor). Academic Press, New York, New York, pp. 39-60.

Schornick, J. C., Jr. and N. M. Ram, 1978. Nitrification in Four Acidic Streams in Southern New Jersey. U.S. Geological Survey Water Resources Investigation 77-121, U.S. Geological Survey, Trenton, New Jersey, 50 pp.

Whittaker, R. H., 1979. Vegetational Relationships of the Pine Barrens. In: Pine Barrens: Ecosystem and Landscape, R. T. T. Forman (Editor). Academic Press, New York, New York, pp. 315-331.

Yuretich, R. F., D. A. Crerar, D. J. J. Kinsman, J. L. Means, and M. P. Borcsik, 1981. Hydrogeochemistry of the New Jersey Coastal Plain. 1. Major Element Cycles in Precipitation and River Water. Chemical Geology 33:1-21. 